Torres, J. L. R., Moreira, L. R., Mageste, J. G., Mazetto Junior, J. C., Silva Júnior, J., Borges, G. V. A., Coelho, L., Lemes, E. M. (2020): Soil attributes, soil organic carbon and relations with rubber-tree morphology in a three-decade-old orchard. Agriculture and Forestry, 66 (1): 191-201.

DOI: 10.17707/AgricultForest.66.1.18

José Luiz Rodrigues TORRES ${ }^{1}$, Leandro Resende MOREIRA, ${ }^{1}$

Jose Geraldo MAGESTE ${ }^{2}$, José Carlos MAZETTO JUNIOR ${ }^{2}$, Jorge da SILVA JÚNIOR, ${ }^{2}$ Gabriel Valeriano Alves BORGES ${ }^{1}$, Lísias COELHO ${ }^{2}$, Ernane Miranda LEMES ${ }^{2 *}$

\title{
SOIL ATTRIBUTES, SOIL ORGANIC CARBON AND RELATIONS WITH RUBBER-TREE MORPHOLOGY IN A THREE-DECADE-OLD ORCHARD
}

\section{SUMMARY}

Successful establishment of a rubber tree plantation may be affected by the initial soil management at the time of planting. However, research on the longterm development of rubber tree plantations and initial soil treatment is scarce. Thus, this study evaluated agronomic characteristics, organic carbon and its stock and their relation to soil attributes in a 32-year-old rubber tree plantation. The experiment adopted a randomized block design with two rubber tree clones (RRIM 600 and FX 2261) and five planting systems (P1: 0.4 x $0.6 \mathrm{~m}$ planting hole; P2: 0.35 x 0.4 m planting hole; P3: 0.45 x 0.45 m furrow; P4: 0.35 x 0.8 m planting hole; P5: $0.25 \times 0.5$ m planting hole) with four replications. The trunk circumference at breast height, height of first bifurcation, bark thickness, total organic carbon in litterfall and carbon stocks in soil were evaluated. The planting systems used for the rubber trees and clones did not influence the trunk circumference at breast height or height of first bifurcation. The bark thickness of FX 2261 was greater than that of RRIM 600. The soil's physical attributes were not affected by different planting systems or clones. The soil of the rubber tree plantation includes significant amounts of carbon absorbed from the atmosphere as $\mathrm{CO}_{2}$.

Keywords: Hevea brasiliensis, tree biometrics, bark thickness, litterfall, soil carbon stock.

\section{INTRODUCTION}

Rubber-tree (Hevea brasiliensis Muell Arg.) is native of the Amazon region and belongs to the Euphorbiaceae family. Plantations can be cultivated in several Brazilian regions since there are rubber-tree clones well adapted to the

\footnotetext{
$1_{*}$ (corresponding author: ernanefito@gmail.com) Instituto Federal do Triângulo Mineiro (IFTM). Uberaba, BRAZIL.

${ }^{2}$ Instituto de Ciências Agrárias (ICIAG), Universidade Federal de Uberlândia (UFU). Uberlândia, BRAZIL.

Notes: The authors declare that they have no conflicts of interest. Authorship Form signed online. 
diverse climatic variations found in the country. In addition to latex production, rubber-tree plantations can be used to recover deforested and degraded areas, because the cover provided by the canopy and litter deposition protect the soil against erosion, maintain moisture and cycle nutrients (Naime et al. 2009), and also, can store significant amounts of carbon in tree biomass, in soil and in the latex produced, which is a raw material for many industrial products (Diniz et al. 2015).

The cultivation of rubber-trees has promoted the recovery and improvement of soil attributes such as aeration, physical structure, water retention capacity, nutrient cycling and the stock of carbon in soil (CStk) (Chaer \& Tótola 2007). Adequate soil management can enhance soil physical and chemical properties recovering natural fertility and increasing the sustainability of the agroecosystem (Cardoso et al. 2010). The quantification of these changes is very important to improve the management of tree plantations (Neves et al. 2007).

The cultivation of long cycle forest species, whose economic uses are not dedicated exclusively to wood production, has comparative advantages in relation to the short-cycle tree species because carbon remains stored in the vegetation for longer periods (Cotta et al. 2008). Carbon fixation in soil is a natural process related to the transference of atmospheric carbon to the litter decomposition process in soil. Lal (2006) emphasizes that 5 to $15 \%$ of the total soil biomass is transformed into humic and fulvic acids. This phenomenon depends on physical, chemical and biological characteristics of soil, climate, nature of the deposited material and on crop management.

The increase of CStk occurs slowly in forest ecosystems through biomass (mostly plant residues) annually deposited in the form of fallen leaves and dead roots. Pandey et al. (2007) further highlighted that in forest ecosystems, the main contribution of organic matter occurs via production, accumulation and decomposition of litter, which is a fundamental process of carbon cycle in the ecosystems. This litter deposition is directly related to silvicultural management, especially in regions of high temperatures and rainfall throughout the year (Lal 2005). Epron et al. (2004) also emphasized that CStk in soils of rubber-tree plantations is a function of plantation age, soil textural class, climate, and management practices.

Moreover, the relation between organic carbon and carbon stock with soil physical attributes in different production systems became a critical practice and is frequently present in discussions in the scientific community. In this context, this study evaluated the tree characteristics, organic carbon and its stock and related them with the soil attributes of a rubber-tree plantation.

\section{MATERIAL AND METHODS}

The experimental area

This study was conducted in an experimental area of the Federal Institute of Triângulo Mineiro (Campus Uberaba), located in Uberaba, State of Minas Gerais, located at 19 $39^{\prime} 19^{\prime \prime} \mathrm{S}$ and $47^{\circ} 57^{\prime} 27^{\prime \prime} \mathrm{W}, 795 \mathrm{~m}$ above sea level. The 
rubber-trees were planted in January 1986 in an area that was a degraded natural pasture covered by species of the genus Brachiaria (Trin.) Griseb grass.

\section{The region's climate}

The climate of the region, according to Köppen, is classified as Cwa, i.e. tropical hot, with hot rainy summer and cold, dry winter, with average annual precipitation and temperature of $1600 \mathrm{~mm}$ and $21^{\circ} \mathrm{C}$, respectively (Alvares et al. 2013).

\section{Soil type}

The soil in the area was classified as a dystrophic Red Latosol, medium texture (Santos et al. 2013). After 32 years, the analysis of the soil superficial layer, down to $0.2 \mathrm{~m}$ depth showed: $210,710,80 \mathrm{~g} \mathrm{~kg}^{-1}$ of clay, sand and silt, respectively; $\mathrm{pH}\left(\mathrm{H}_{2} \mathrm{O}\right): 5.5 ; \mathrm{P}\left(\mathrm{Mehlich}^{-1}\right): 3.3 \mathrm{mg} \mathrm{dm}{ }^{-3} ; \mathrm{K}^{+}: 2.9, \mathrm{Ca}^{2+}: 22, \mathrm{Mg}^{2+}$ : 10, and $\mathrm{H}^{+} \mathrm{Al}$ : $20 \mathrm{mmol} \mathrm{dm}^{-3}$; organic matter $(\mathrm{OM}): 16 \mathrm{~g} \mathrm{dm}^{-3}$ and $68 \%$ of base saturation.

\section{Experimental design}

The experimental design was a randomized blocks, as a 2x5 factorial, with two clones (RRIM 600 and FX 2261) and five different planting systems (P1- 0.4 $\mathrm{m}$ by $0.6 \mathrm{~m}$ depth planting hole, made with post-hole digger (control); P2 - $0.3 \mathrm{~m}$ by $0.4 \mathrm{~m}$ depth planting hole, made with post-hole digger (these treatments had the upper soil layer returned to the bottom of the hole); P3- $0.45 \mathrm{~m}$ wide by 0.45 $\mathrm{m}$ depth furrow (soil was returned to the furrow with hoe); P4- planting hole made with a drill attached to a tractor, with $0.35 \mathrm{~m}$ in diameter $\mathrm{x} 0.8 \mathrm{~m}$ depth, without lateral scarification (sandy soil); P5- planting hole made with a drill attached to a tractor, with $0.25 \mathrm{~m}$ in diameter $\times 0.5 \mathrm{~m}$ of depth), with four replications.

Limestone (29.5 and 19.5\% of $\mathrm{CaO}$ and $\mathrm{MgO}$, respectively) was broadcast applied at $2 \mathrm{t} \mathrm{ha}^{-1}$. Pre planting fertilization was done in the planting hole or in the furrow with $200 \mathrm{~g}$ of 6-30-6 + 6 (NPK $+\mathrm{Mg}$ ), $10 \mathrm{~g}$ of FTE Br-12 and $0.06 \mathrm{~g}$ Borax $0.3 \%$. This same fertilization was repeated in the subsequent year plus 0.15 $\mathrm{kg} \mathrm{KCl}$, as side dressing. The soil surface around the saplings (0.8 m diameter) was weeded during the first two years after planting. Subsequently, weed management was done with a rotary brush cutter between planting rows as needed. No other cultural practices or mineral fertilization was done in the area for 32 years.

The useful experimental plot was $160 \mathrm{~m} 2$ and consisted of 8 plants spaced $8 \times 2.5 \mathrm{~m}$, equivalent to a planting density of 500 plants ha ${ }^{-1}$.

The following rubber-tree morphological parameters were evaluated: circumference at breast height (CBH); height of the first bifurcation (HFB) from soil level, and bark thickness (BT).

\section{Physical Attributes}

Undisturbed soil samples were collected by the method of volumetric rings, in $48 \times 53 \mathrm{~mm}$ (diameter $\mathrm{x}$ height) rings coupled to a Uhland auger, at 0 0.05 and $0.05-0.10 \mathrm{~m}$ to determine soil density (SD). These samples were 
saturated, weighed, and dried in an oven at $105^{\circ} \mathrm{C}$ for 24 hours. Pore size distribution was determined with the same undisturbed sample, which was saturated with water for 24 hours, and then subjected to suction at $0.60 \mathrm{~m}$ of water column height for the estimation of macro-porosity (Ma), total porosity (TP) and micro-porosity (Mi) according to Embrapa (2017).

\section{Soil water content}

The second set of soil samples was collected at the same day and depths to evaluate the soil water content, which was homogenized to obtain the moist and dry weights of the soil. These samples were packed in aluminum containers, weighed and dried in forced circulation oven at $105^{\circ} \mathrm{C}$ for 24 hours when the volumetric soil water was estimated (Embrapa 2017).

Determination of total organic carbon

In each treatment, $0.5 \times 0.5 \mathrm{~m}$ and $0.5 \mathrm{~m}$ depth trenches were opened. Two undisturbed samples were collected in each trench with the aid of a volumetric ring (Teixeira et al. 2017), one sample to determine soil density and the other one to determine the content of total organic carbon (TOC), at the soil depths of 0 0.05 and $0.05-0.10 \mathrm{~m}$. TOC content was determined according to the methodology of Walkley \& Black (1934) adapted by Yeomans \& Bremner (1988).

Organic carbon stock of the soil

Carbon stocks (CStk) in the soil were calculated according to the method of Fernandes and Fernandes (2013), using the following equation:

CStk $\left(\mathrm{t} \mathrm{ha}^{-1}\right)=(\mathrm{C} \times \mathrm{SD} \times \mathrm{e}) / 10$;

where CStk ( $\left.\mathrm{t} \mathrm{ha}^{-1}\right)$ is the carbon stocked in soil, C is the total organic carbon (TOC) in the considered layer $\left(\mathrm{g} \mathrm{kg}^{-1}\right)$; SD is soil density $\left(\mathrm{Mg} \mathrm{m}^{-3}\right)$ and e is the thickness of the soil layer considered (cm).

\section{Quantification of litterfall}

The amount of litterfall was estimated on a single occasion. The samples were collected between plants using a $0.5 \times 0.5\left(0.25 \mathrm{~m}^{2}\right)$ metal frame, where all the rubber-tree residues were collected. In each experimental plot, four simple litterfall samples were collected to make one composite sample $(n=40)$.

The samples were packed in paper bags, dried in a forced circulation oven at $65^{\circ} \mathrm{C}$ for 72 hours, when dry mass was estimated. The stock of litter for each clone was quantified through the expression: Stock of litter $\left(\mathrm{t} \mathrm{ha}^{-1}\right)=$ mass $(\mathrm{t}) \mathrm{x}$ area of the metal frame (ha).

Statistical analysis

The results were submitted to analysis of the normality of the distribution of errors (Lilliefors' test) and homogeneity of variances (Cochran's test). Given the assumptions of normality and homogeneity were accepted, the values were submitted to analysis of variance (ANOVA) and the averages compared by Tukey's test at $5 \%$ probability $(\mathrm{p}<0.05)$. The software $\mathrm{R}$ Core Team was used for the statistical analysis. 


\section{Morphological parameters}

\section{RESULTS AND DISCUSSION}

There were no significant differences $(\mathrm{p}<0.05)$ among treatments (planting systems) or clones for circumference at breast height (CBH) and height of the first bifurcation (HFB), which ranged from 0.64 to $0.8 \mathrm{~m}$ and from 3.18 to $4.87 \mathrm{~m}$ for the clone RRIM 600, and from 0.68 to $0.88 \mathrm{~m}$ and from 3.49 to $4.56 \mathrm{~m}$ for the clone FX 2261, respectively (Table 1). Such dimensions of CBH and HFB the rubber-tree plants evaluated in this study indicate that they are suitable for latex production.

Table 1. Circumference at breast height (CBH), bark thickness (BT) and height of first bifurcation (HFB) of RRIM 600 (RR) and FX 2261 (FX) rubbertree clones subjected to different planting systems after 32 years.

\begin{tabular}{|c|c|c|c|c|c|c|c|c|c|}
\hline \multirow{2}{*}{$\begin{array}{l}\text { Planting } \\
\text { System }\end{array}$} & \multicolumn{3}{|c|}{ CBH (m) } & \multicolumn{3}{|c|}{ BT (cm) } & \multicolumn{3}{|c|}{$\mathrm{FBH}(\mathrm{m})$} \\
\hline & $\mathrm{RR}$ & FX & $\begin{array}{c}\text { Avera } \\
\text { ge }\end{array}$ & $\mathrm{RR}$ & FX & $\begin{array}{c}\text { Avera } \\
\text { ge }\end{array}$ & $\mathrm{RR}$ & $\mathrm{FX}$ & Average \\
\hline & \multicolumn{3}{|c|}{$\mathrm{m}$} & \multicolumn{3}{|c|}{$\mathrm{cm}$} & \multicolumn{3}{|c|}{$\mathrm{m}$} \\
\hline P1 & 0.80 & 0.86 & $0.83 a^{*}$ & 1.09 & 1.17 & $1.13 \mathrm{a}$ & 3.18 & 3.81 & $3.49 \mathrm{a}$ \\
\hline P2 & 0.71 & 0.76 & $0.73 a$ & 1.09 & 1.15 & $1.12 \mathrm{a}$ & 4.34 & 4.45 & $4.39 \mathrm{a}$ \\
\hline P3 & 0.69 & 0.79 & $0.74 a$ & 1.06 & 1.19 & $1.12 \mathrm{a}$ & 4.16 & 3.79 & $3.97 \mathrm{a}$ \\
\hline P4 & 0.64 & 0.88 & $0.76 \mathrm{a}$ & 1.05 & 1.17 & $1.11 \mathrm{a}$ & 4.87 & 4.26 & $4.56 \mathrm{a}$ \\
\hline P5 & 0.69 & 0.68 & $0.68 \mathrm{a}$ & 1.10 & 1.12 & $1.11 \mathrm{a}$ & 3.91 & 4.97 & $4.44 \mathrm{a}$ \\
\hline Average & $0.71 \mathrm{a}$ & $0.79 a$ & & $1.08 \mathrm{~b}$ & $1.16 \mathrm{a}$ & & $4.1 \mathrm{a}$ & $4.2 a$ & \\
\hline CV (\%) & \multicolumn{3}{|c|}{17.03} & \multicolumn{3}{|c|}{6.99} & \multicolumn{3}{|c|}{14.85} \\
\hline
\end{tabular}

* = averages followed by different letters differ by the Tukey test $(\mathrm{p}<0.05) . \mathrm{P} 1=$ In pits of $0.4 \mathrm{~m}$ by $0.6 \mathrm{~m}$ depth, made with post-hole digger (control); P2 = In the pits with $0.3 \mathrm{~m}$ by $0.4 \mathrm{~m}$ depth, made with post-hole digger; P3 = Furrow with $0.45 \mathrm{~m}$ wide by $0.45 \mathrm{~m}$ depth; $\mathrm{P} 4=$ In holes made with a drill attached to a tractor, with $0.35 \mathrm{~m}$ in diameter $\mathrm{x} 0.8$ $\mathrm{m}$ depth; $\mathrm{P}_{5}=$ In holes made with a drill attached to a tractor, with $0.25 \mathrm{~m}$ in diameter $\mathrm{x}$ $0.5 \mathrm{~m}$ of depth. CV: coefficient of variation.

These variables are directly related to latex productivity since rubber-trees with greater HFB and $\mathrm{CBH}$ have greater production of dry rubber (Costa et al. 2010). Pereira and Pereira (2001) emphasized that rubber-tree plants should reach the minimum $\mathrm{CBH}$ at the earliest age possible because this is the first parameter considered to start tapping activity, which must range from 0.45 to $0.5 \mathrm{~m}$.

The BT values found differed among clones $(\mathrm{p}<0.05)$ with the BT of clone FX 2261 approximately 7\% thicker than the bark of clone RRIM 600. The $\mathrm{CBH}$ 
and the BT correlate phenotypically, indicating that plants with great $\mathrm{CBH}$ tend to have great BT and, therefore, greater productivity (Campbell et al. 2010; Mosque \& Oliveira, 2010). According to the results found in the present study, the clone FX 2261 has the potential for superior latex production due to thicker bark when compared with the clone RRIM 600. However, this similar response between FX 2261 and RRIM 600 was not observed by Melo et al. (2004), who found that RRIM 600 presented the greatest latex production among the genotypes evaluated.

\section{Soil physical attributes}

The table of analysis of variance (F test) of the interactions among clones, planting systems and soil depths, shows that there were no significant interactions $(\mathrm{p}>0.05)$ for the attributes evaluated, nor for the factors individually (Table 2).

Table 2. Probability of the analysis of variance (F test) of the triple interaction (clones $\mathrm{x}$ planting systems $\mathrm{x}$ soil depths) for soil density (SD), macroporosity (Ma), microporosity (Mi), total porosity (TP), and macropore density (Ma / TP).

\begin{tabular}{|c|c|c|c|c|c|c|c|}
\hline \multirow{2}{*}{ Source of Variation } & \multirow{2}{*}{$d f$} & SD & Ma & $\mathrm{Mi}^{\text {ns }}$ & \multicolumn{2}{|c|}{ TP } & Ma/TP \\
\cline { 3 - 8 } & & \multicolumn{5}{|c|}{$p$ value } \\
\hline Clone & 1 & 0.7617 & 0.2337 & 0.6932 & 0.3448 & 0.2015 \\
\hline Planting syst. & 4 & 0.3665 & 0.2171 & 0.1948 & 0.5602 & 0.1545 \\
\hline Soil depth & 1 & 0.0001 & 0.0009 & 0.7945 & 0.0007 & 0.0056 \\
\hline Clone*Planting syst. & 4 & 0.7279 & 0.1390 & 0.7680 & 0.2446 & 0.1832 \\
\hline Clone*Soil depth & 1 & 0.0606 & 0.8591 & 0.3252 & 0.2722 & 0.7730 \\
\hline Planting syst.*Soil depth & 4 & 0.9618 & 0.9902 & 0.1390 & 0.3943 & 0.8591 \\
\hline Clones* Planting & 4 & 0.8674 & 0.8593 & 0.6291 & 0.9898 & 0.6249 \\
\hline syst.*Soil depth & & & & & & \\
\hline CV (\%) & & 6.93 & 26.27 & 15.04 & 9.72 & 22.74 \\
\hline
\end{tabular}

These results corroborate with other studies in rubber-tree plantations, which, after its establishment, regardless of the planting technique, the system stabilizes in time. The annual deposition of litter on soil surface, with the renewal of the rubber-trees root system and invasive plants that colonize the nearby areas, provide a high input of organic matter causing positive changes in soil structure (Eucalyptus - Chaer \& Tótola, 2007; Eucalyptus, soybean, rice, Brachiaria Neves et al. 2007; native Brazilian forests - Cardoso et al. 2010). 
The homogeneous responses from the different planting systems are a result of soil stability since the planting process - more than three decades earlier. Also, the regular input of organic matter on the soil surface resulted in significant improvements in the soil microporosity in both soil layers (Table 3).

Table 3. Soil density (SD), macroporosity (Ma), microporosity (Mi), total porosity (TP) and macropore density (Ma / TP) at different soil depths in a 32year-old rubber-tree plantation. Uberaba, MG, 2016.

\begin{tabular}{|c|c|c|c|c|c|}
\hline Soil depth & SD & Ma & Mi & TP & Ma/PT \\
\hline$(\mathrm{m})$ & $\mathrm{kg} \mathrm{dm}{ }^{-3}$ & \multicolumn{5}{|c|}{$\%$} \\
\hline $0-0.05$ & $1.34 \mathrm{a}^{*}$ & $23.90 \mathrm{a}$ & $31.22 \mathrm{a}$ & $55.13 \mathrm{a}$ & $43.49 \mathrm{a}$ \\
\hline $0.05-0.1$ & $1.45 \mathrm{~b}$ & $18.73 \mathrm{~b}$ & $31.54 \mathrm{a}$ & $50.27 \mathrm{~b}$ & $36.59 \mathrm{~b}$ \\
\hline CV (\%) & 6.93 & 26.27 & 15.04 & 9.72 & 22.74 \\
\hline
\end{tabular}

$*=$ averages followed by different letters in each column differ by the Tukey test $(\mathrm{p}<0.05)$.

Soil micropores are one of the most stable soil characteristics, especially in stabilized systems, such as rubber-tree plantations. In planting systems with great soil movement and short cultural cycles, as in soybean, maize and wheat, the micropores are effectively changed after each soil mobilization (Albuquerque et al. 1995; Bertol et al. 2004; Sales et al. 2016).

According to Torres et al. (2015), the deposition of plant residues on the soil protects it from erosion caused by rainfall and reduces soil moisture fluctuation. Besides, plant residues provide energy as organic matter to the soil microbiata, which produces substances responsible for the formation and stabilization of soil aggregates. These effects, added to the aggregation promoted by rubber-tree roots, reduce the variations in soil density and microporosity of soil top layers.

The density of soil macropores (Ma/TP) is an indication of favorable conditions for root development. Taylor and Stewart (1972) highlighted that approximately one-third of the total soil porosity are macropores, and that lower values of macropores indicate soil compaction - compaction that can reduce space for satisfactory root development. The critical threshold of Ma considered prejudicial for root growth is $10 \%$ of the soil space, and an ideal proportion for annual crop production is about $1 / 3$ of Ma (33\%) and 2/3 of Mi (67\%) (Kiehl 1979).

In this study, the density of macropores in the soil layers evaluated was greater than the optimal density (Ma/TP $>0.33$ ); therefore, with enough space for unrestrained root growth (Table 3). Macropore density in the top $0.10 \mathrm{~m}$ of the soil surface indicates an influence of the degradation and incorporation of organic matter in the soil physical attributes. This superficial layer is in direct contact 
with plant debris fallen from the rubber-trees and from the Brachiaria grass, which was the most common weed in the area.

\section{Quantity of litter and carbon stock}

No interaction was observed between clones and planting systems, nor differences between the levels in each factor ( $>>0.05)$, for the amount of litter on the ground or the total organic carbon (TOC) found in the layer of $0-0.10 \mathrm{~m}$. The average amount of litter and TOC were $26.38 \mathrm{t} \mathrm{ha}^{-1}(\mathrm{CV}=29.80 \%)$ and $207.62 \mathrm{~g}$ $\mathrm{kg}^{-1}$ of soil ( $\left.\mathrm{CV}=15.35 \%\right)$, respectively.

For Pimentel Gomes and Garcia (2002), the variability of an attribute can be classified according to the magnitude of its coefficient of variation (CV), which can be low when it is less than $10 \%$, moderate when between 10 and $20 \%$, high between 21 to $30 \%$ and very high when above $30 \%$. The CV (\%) values for the amount of litter and TOC were classified as high and moderate, indicating that these variables can considerably change from one sampling place to another. However, for all treatments, there were high inputs of organic matter in the soil under rubber-tree plantation.

The stock of carbon (CStk) in the soil did not show any significant interaction with the planting systems or the rubber-tree clones $(\mathrm{p}>0.05)$, but differed between soil layers $(p=0.0010)$. The top soil layer $(0-0.05 \mathrm{~m})$ presented $7.12 \mathrm{t} \mathrm{ha}^{-1}$, while the second layer $(0.05-0.10 \mathrm{~m})$ presented $5.57 \mathrm{t} \mathrm{ha}^{-1}$ of carbon. These values of carbon stored in the soil indicate that the rubber-tree is a forest species capable of fixing significant amounts of atmospheric carbon into the soil (Cheng et al. 2007; Nizami et al. 2014; Diniz et al. 2015).

Litter decomposition is done by soil microbiota, consuming approximately $80 \%$ of the organic matter present, while transforming the remaining in humic substances (Anderson \& Domsch 1990). The contents and characteristics of soil organic matter are the result of its production and decomposition rates, chemical composition of the plant residues, soil texture, aeration and $\mathrm{pH}$, climate prevalent conditions, soil microbiota diversity and the interaction among all of them (Silva et al. 2009; Nascimento et al. 2010).

In this sense, crop management and soil interactions with the vegetation that fixes carbon are important for increasing organic matter in the soil. Studies are still required to better understand the quality of the plant residues produced by different forest species and their impact on the physical, chemical and biological properties of the soil (Caldeira et al. 2008), as well as the time in which these changes occur. Such studies may assist in the selection of the most appropriate clones for the formation of rubber-tree plantation, promoting a better balance of the ecosystem and contributing to reduce the environmental impact of the activity. 


\section{CONCLUSIONS}

The systems of planting Hevea brasiliensis seedlings did not affect the circumference at breast height nor the height of the first bifurcation, three decades after the establishment of the rubber-tree plantation.

The bark of the clone FX 2261 was significantly thicker than that of RRIM 600 , indicating that FX 2261 has greater potential for latex production.

The soil physical attributes were not affected by the different systems of rubber-tree planting, but differences were observed between the soil layers, indicating that the system has reached environmental stability;

The rubber-tree plantation, regardless of the clone or planting system, incorporates significant amounts of carbon to the soil, in quantities similar or superior to many forest species.

\section{ACKNOWLEDGEMENTS}

To the Federal Institute of Triângulo Mineiro, Campus Uberaba, and Federal University of Uberlândia, Campus Umuarama, for providing infrastructure and personnel; to the Foundation of Support Research of the State of Minas Gerais (FAPEMIG) for financing the project; to the National Council for Scientific and Technological Development (CNPq) and Coordination of Improvement of Higher Level Personnel (CAPES) for granting scholarships.

\section{REFERENCES}

Albuquerque JA, Reinert DJ, Fiorin JE, Ruedell J, Petrere C, Fontinelli F (1995). Rotação de culturas e sistemas de manejo do solo: efeito sobre a forma da estrutura do solo ao final de sete anos. Revista Brasileira de Ciência do Solo, 19: 115-119. http://dx.doi.org/10.1590/S0006-87052008000200020

Alvares CA, Stape JL, Sentelhas PC, Gonçalves JLM, Sparovek G (2013). Köppen’s climate classification map for Brazil. Meteorologische Zeitschrift, http://dx.doi.org/10.1127/0941-2948/2013/0507

Anderson JPE, Domsch KH (1990). A physiological method for quantitative measurement of microbial biomass in soils. Soil Biological Biochemistry, 10: 215221. https://doi.org/10.1016/0038-0717(78)90099-8

Arantes FC, Gonçalves OS, Scaloppi Junior EJ, Moraes MLT, Resende MDV (2010). Ganho genético com base no tamanho efetivo populacional de progênies de seringueira. Pesquisa Agropecuária Brasileira, 45: 1419-1424. http://dx.doi.org/10.1590/S0100-204X2010001200012

Bertol I, Albuquerque JA, Leite D, Amaral AJ \& Zoldan Junior WA (2004). Propriedades físicas do solo sob preparo convencional e semeadura direta em rotação e sucessão de culturas comparadas às do campo nativo. Revista Brasileira de Ciência do Solo, 28: 155-163. http://dx.doi.org/10.1590/S0100-06832004000100015

Caldeira MVW, Vitorino MD, Schaadt SS, Moraes E \& Balbinot R (2008). Quantificação de serrapilheira e de nutrientes em uma Floresta Ombrófila Densa. Semina: Ciências Agrárias, 29(1): 53-68.

Cardoso EL, Silva MLN, Silva CA, Curi N, Freitas DAF (2010). Estoques de carbono e nitrogênio em solo sob florestas nativas e pastagens no bioma Pantanal. Pesquisa Agropecuária Brasileira, 45: 1028-1035. http://dx.doi.org/10.1590/S0100204X2010000900013 
Chaer GM, Tótola MR (2007). Impacto do manejo de resíduos orgânicos durante a reforma de plantios de eucalipto sobre indicadores de qualidade do solo. Revista Brasileira de Ciência do Solo, 31: 1381-1396. http://dx.doi.org/10.1590/S010006832007000600016

Cheng C, Wang R, Jiang J (2007). Variation of soil fertility and carbon sequestration by planting Hevea brasiliensis in Hainan Island. Journal of Environmental Sciences, 19: 348-352. http://dx.doi.org/10.1016/S1001-0742(07)60057-6

Costa RB, Resende MDV, Gonçalves PS, Roa RAR \& Feitosa KCO (2010). Predição de parâmetros e valores genéticos para caracteres de crescimento e produção de látex em progênies de seringueira. Bragantia, 69: 49-56. http://dx.doi.org/10.1590/S0006-87052010000100007

Cotta MK, Jacovine LAG, Paiva HN, Soares CPB, Virgens Filho AC, Valverde SR (2008). Quantificação de biomassa e geração de certificados de emissões reduzidas no consórcio seringueira-cacau. Revista Árvore, 32(6): 969-978. http://dx.doi.org/10.1590/S0100-67622008000600002

Diniz AR, Pereira MG, Balieiro FC, Silva EV, Santos FM, Lisboa FJG Oliveira AB, Cruz RB (2015). Contrasts in areas of rubber-tree clones in regard to soil and biomass carbon stocks. Revista Brasileira de Ciência do Solo, 39:1378-1385. http://dx.doi.org/10.1590/01000683rbcs20140274

Epron D, Nouvellonb Y, Roupsard O, Mouvondy W, Mabiala A, Saint-André L, Joffre R, Jourdan C, Bonnefond JM, Berbigiere P, Hamel O (2004). Spatial and temporal variations of soil respiration in a Eucalyptus plantation in Congo. Forest Ecology and Management, 202(3): 149-160. http://dx.doi.org/10.1016/j.foreco.2004.07.019

Fernandes AF, Fernandes AHBM (2013). Atualização dos métodos de cálculo dos estoques de carbono do solo sob diferentes condições de manejo. Corumbá: Embrapa Pantanal, 2013. 5p. (Embrapa Pantanal. Comunicado Técnico, 95). Available at: https://www.infoteca.cnptia. embrapa.br/bitstream/doc/981613/1/COT95.pdf [verified 11 June 2019].

Lal R (2005). Soil carbon sequestration impacts on global climate change and food security. Science, 304: 1623-1627. http://dx.doi.org/10.1126/science.1097396

Lal R. 2006. Soil carbon sequestration in Latin America. In: Lal R, Cerri CC, Bernoux M, Etchevers J, Cerri E. (Eds.), Carbon sequestration in soil of Latin America, FPP, New York.

Melo R F, Oliveira L E M, Mesquita A C \& Delú Filho N (2004). Variação sazonal de algumas características nutricionais e bioquímicas relacionadas com a produção de látex em clones de seringueira [Hevea brasiliensis (Wild.) Muell. Arg.)], em Lavras-MG. Ciência e Agrotecnologia, 28(6): 1326-1335. https://dx.doi.org/10.1590/S1413-70542004000600015

Mesquita A, Oliveira LEM (2010). Características anatômicas da casca e produção do látex em plantas de seringueira enxertadas. Acta Amazônica, 40: 241-246. http://dx.doi.org/10.1590/S0044-59672010000200001

Naime UJ, Lumbreras JF, Motta PEF (2009). Zoneamento Agroecológico da Seringueira no Estado do Rio de Janeiro. In: Oliveira, A.B.; Carmo, C.A.F.S.; Cruz, R.B. (Ed.) A cultura da seringueira no estado do Rio de Janeiro: Perspectivas e recomendações técnicas. Niterói: Pesagro.

Nascimento PC, Lani JL, Mendonça ES, Zoffoli HJO \& Peixoto HTM. 2010. Teores e características da matéria orgânica de solos hidromórficos do Espírito Santo. Revista Brasileira de Ciência do Solo; 34: 339-348. http://dx.doi.org/10.1590/S0100-06832010000200007 
Neves CMNN, Silva MLN, Curi N, Cardoso EL, Macedo RLG, Ferreira MM \& Souza FS. 2007. Atributos indicadores da qualidade do solo em sistema agrossilvipastoril no noroeste do Estado de Minas Gerais. Scientia Forestalis, 74: 45-53. http://www.ipef.br/publicacoes/scientia/nr74/cap05.pdf.

Nizami SM, Yiping Z, Liqing S, Zhao W, Zhang X. 2014. Managing carbon sinks in rubber (Hevea brasiliensis) plantation by changing rotation length in SW China. PLoS One, 9: 115-234. https://doi.org/10.1371/journal.pone.0115234

Pandey RR, Sharma G, Tripathi SK, Singh AK (2007). Litterfall, litter decomposition and nutrient dynamics in a subtropical natural oak forest and managed plantation in northeastern India. Forest Ecology and Management, 240: 96-104. https://doi.org/10.1016/j.foreco.2006.12.013

Pereira AV, Pereira EBC (2001). Perspectivas da cultura da seringueira no cerrado. Ciência e Pesquisa, 34: 1-6.

Sales OS, Portugal AF, Moreira JAA, Kondo MK, Pegoraro RF (2016). Qualidade física de um Latossolo sob plantio direto e preparo convencional no semiárido. Revista Ciência Agronômica, 47(3): 429-438. http://www.scielo.br/pdf/rca/v47n3/18066690-rca-47-03-0429.pdf

Santos HG, Jacomine PKT, Anjos LHC, Oliveira VA, Lumbreras JF, Coelho MR, Almeida JA, Cunha TJF, Oliveira JB (2013). Sistema brasileiro de classificação de solos. 3.ed. rev. e ampl. Brasília: Embrapa.

Silva LG, Mendes IC, Reis FB, Fernandes MF, Melo JT, Kato E (2009). Atributos físicos, químicos e biológicos de um Latossolo de cerrado em plantio de espécies florestais. Pesquisa Agropecuária Brasileira, 44: 613-620. https://doi.org/10.1590/S0100-204X2016000900005

Taylor AS, Ashcroft GL (1972). Physical edaphology - The physics of irrigated and non irrigated soils. San Francisco, W.H. Freeman.

TeixeirA PC, Donagemma GK, Fontana A, Teixeira WG (2017). Manual de Métodos de Análise de Solos. 3.ed. rev. e ampl. Rio de Janeiro: Embrapa.

Torres JLR, Pereira MG, Assis RL, Souza ZM (2015). Atributos físicos de um Latossolo Vermelho cultivado com plantas de cobertura, em semeadura Direta. Revista $\begin{array}{lllll}\text { Brasileira de Ciência do } & \text { 428-437. }\end{array}$ http://dx.doi.org/10.1590/01000683rbcs20140597

Yeomans JC, Bremner JMA (1988). Rapid and precise method for routine determination of organic carbon in soil. Communications in Soil Science Analysis, 19(13): 14671476. https://doi.org/10.1080/00103628809368027 